\title{
Kompor Biomassa Sebagai Salah Satu Teknologi Tepat Guna Masyarakat Pedesaan
}

Jhonni Rahman ${ }^{1}$

${ }^{1}$ Program Studi Teknik Mesin, Fakultas Teknik, Universitas Islam Riau, Jln. Kaharuddin Nasution Km. 113 Marpoyan, Pekanbaru, Riau, Indonesia - 28284

*Penulis koresponden: jhonni rahman@eng.uir.ac.id

\section{Info Artikel}

\section{Riwayat:}

Dikirim 1 Desember 2021

Direvisi 30 Desember 2021

Diterima 31 Desember 2021

\section{Kata Kunci:}

Tungku tradisional Efisiensi pembakaran Kompor biomassa Kesehatan

\begin{abstract}
Abstrak
Sistem pembekaran yang terjadi pada tunggu/kompot biomassa tradisional memberi berdampak buruk terhadap kesehatan pengguna karena efesiensi pembakaran yang rendah mengakibatkan timbulnya banyak asap yang menggangu kesehatan pengguna. Pada kegiatan community service ini, diperkenalkan sebuah model kompor biomassa yang telah dikembangkan dan memiliki sistem pembakaran yang lebih sempurna, sehingga efesiensinya jauh lebih baik. Kegiatan ini berbentuk penyuluhan atau sosialisasi yang menjelaskan kepada masyarakat tentang kompor biomassa semi gasifikasi, nilai ekonomis dari penggunaan kompor biomassa semi gasifikasi, kelebihan menggunakan kompor biomassa, dan hubungan efesiensi pembakaran terhadap pembakaran, dampak positif bagi kesehatan serta bagian-bagian penting dari kompor biomassa semi gasifiksi. Setelah itu dilanjutkan dengan diskusi dan tanya jawab untuk memantapkan pemahaman mereka terhadap kompor biomassa yang telah dikembangkan serta mencerahkan keraguan mereka. Kegiatan ini berjalan lancar dan diterima baik oleh masyarakat, terlihat dari keaktifan mereka dalam berinteraksi dengan pemateri tentang kompor biomassa selama kegiatan berlangsung.
\end{abstract}

\section{PENDAHULUAN}

Sebagai daerah agraris Riau merupakan salah satu daerah di Indonesia yang memiliki potensi yang sangat besar sebagai sumber energy yaitu biomassa. Dengan banyaknya biomassa yang ada di propinsi Riau, masyarakat pedesaan dapat memanfaatkan biomassa tersebut untuk berbagai kebutuhan. Salah satu bentuk pemanfaatan biomassa yang sering dilakukan di daerah pedesaan ialah sebagai bahan bakar untuk keperluan memasak rumah tangga sehari-hari. Namun, pemanfaatan biomassa sebagai bahan bakar di pedesaan masih belum optimal karena masih menggunakan cara dan alat tradisional yang memberi dampak negative bagi pengguna (Pathak et al., 2019). Diantaranya adalah permasalahan ganguan pernafasan pernafasan yang sering ditemukan pada masyarakat pengguna kompor masak tradisional (Robin, et al., 1996). Bahkan tidak sedikit masalah tersebut merambah ke anak-anak dibawah umur yang secara tidak sengaja menghirup asap hasil pembakaran dari kompor tradisional ketika memasak. WHO telah mengeluarkan keterangan bahwa lebih dari 10\% kematian dini yang terjadi pada anak-anak dibawah 5 tahun akibat penyakit pneumonia yang bersumber dari partikel-partikel halus yang berasal dari asap pembakaran kompor tradisional (Statistik WHO, 2014).

Dan kasus seperti ini sering terjadi di daerah pedesaan yang memiliki ekonomi relative rendah. Sehingga meskipun mereka menyadari atau merasakan efek buruk dari asap kompor 
tradisional, mereka masih terpaksa untuk tetap menggunakannya. Hal ini terjadi karena beberapa kemungkinan alasan, bisa jadi dikarenakan susahnya mendapatkan bahan bakar fosil dan gas karena wilayah yang sulit terjangkau. Bisa jadi karena faktor ekonomi yang tidak memungkinkan bagi masyarakat ekonomi rendah untuk membeli bahan bakar fosil dan gas. Ditambah lagi dengan harga bahan bakar fosil yang terus melambung. Sementara itu di pedesaan masyarakat tidak membutuhkan dana sedikitpun untuk mendapatkan bahan bakar mengingat sumber bahan bakar alami tersedia melimpah disekitar mereka. Sehingga mereka bisa menyisihkan uang mereka untuk keperluan penting lainnnya. Gambar 1 adalah contoh kondisi masyarakat yang menggunakan kompor biomassa tradisional untuk memasak. Foto ini menggambarkan salah satu kebiasaan masyarakat setempat yang sering memasak sambil menggendong anak mereka.

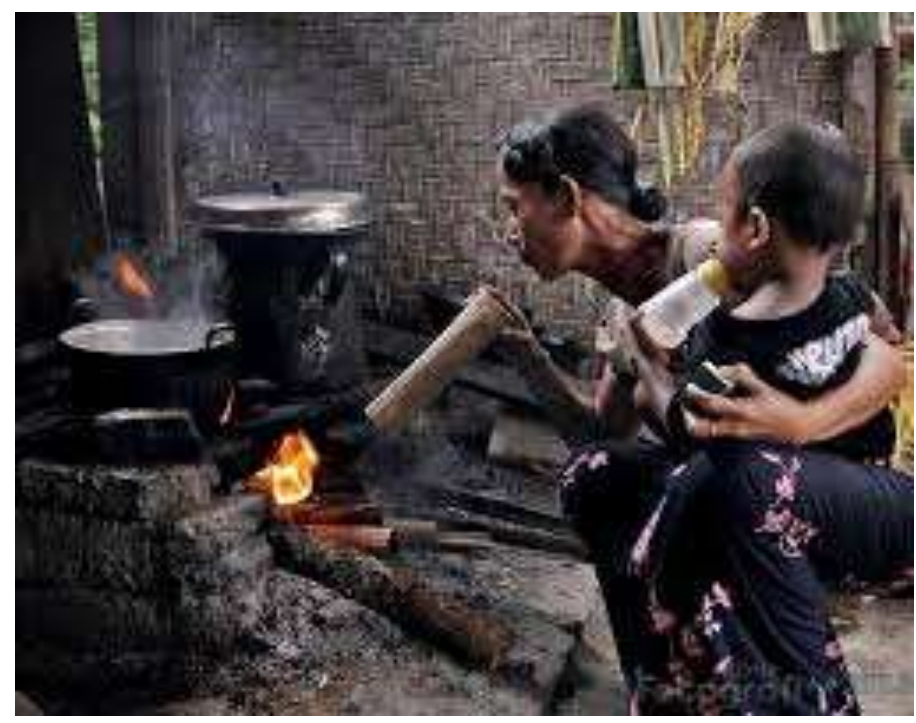

Gambar 1. Tungku masak tradisional di pedesaan (Giyanto, 2020)

Dalam ilmu konversi energi, timbulnya banyak asap akibat pembakaran menunjukkan proses pembakaran secara tradisional masih terlalu jauh dari sempurna. Menurut hasil penelitian yang telah dilakukan oleh para peneliti dalam maupun luar negeri efisiensi pembakaran dengan menggunakan cara tradisional masih sangat rendah yaitu sebesar kurang dari $15 \%$ (tergantung bahan bakar) (Julita et al., 2019). Hal ini menunjukkan bahwa potensi energi yang ada pada bahan bakar biomassa masih belum dimamfaatkan dengan baik, sehingga sering menjadi pemborosan dalam penggunaan bahan bakar biomassa.

Optimalisasi performa biomassa untuk kebutuhan memasak, dapat dilakukan pada dua aspek, yaitu aspek bahan bakar dan aspek alat pembakaran (dalam hal ini adalah kompor). Optimalisasi biomassa dalam aspek bahan bakar biasanya dilakukan dengan membuat bahan bakar biomassa menjadi bentuk yang lebih mudah digunakan dan performa yang lebih baik seperti briket, peningkatan kualitas, dan lain lain (Elfiano, 2013; Elfiano et al., 2014). Sedangkan dalam aspek media pembakaran dapat dikembangkan melalui pembuatan model kompor biomassa yang mampu menghasilkan proses pembakaran yang lebih sempurna (Rahman, 2015). Untuk masyarakat pedesaan pengembangan kompor biomassa merupakan solusi yang paling tepat dalam mengurangi masalah ditinjau dari berbagai aspek. Sejauh ini sudah banyak model model kompor biomassa yang memiliki efesiensi pembakaran yang memiliki efesiensi pembakaran yang lebih baik dari pada kompor tradisional, seperti kompor biomassa gasifikasi yang telah dikembangkan saat ini (Julita et al., 2019). Sistem pembakaran yang terjadi pada kompor gasifikasi jauh lebih bersih dari pada kompor tradisional karena emisi yang dihasilkan jauh lebih sedikit. Sehingga tidak hanya less risk bagi pengguna tetapi juga hemat bahan bakar. Dan yang terpenting adalah penggunaan kompor biomassa dengan performa yang lebih baik mampu meningkatkan Kesehatan pengguna karena efek buruk dari asap sisa pembakaran dapat diminimalisir dengan baik (Adler, 2010).

Kegiatan community service melalui penyuluhan ini dilakukan untuk beberapa tujuan, yaitu menginformasikan kepada masyarakat setempat dampak negative asap bagi kesehatan pengguna dan orang terdekat mereka yang ditimbulkan ketika memasak menggunakan kompor/tungku tradisional. 
Selanjutnya, kegiatan ini juga dilakukan untuk memperkenalkan salah satu model kompor biomassa gasifikasi natural yang dikembangkan oleh Prodi Teknik Mesin Universitas Islam Riau (UIR) sebagai salah satu solusi implementasi teknologi tepat guna ditengah-tengah masyarakat serta kelebihannya dibandingkan kompor biomassa tradisional. Gambar 2 adalah foto dari kompor biomassa semi gasifikasi hasil pengembangan Prodi Teknik Mesin UIR (Rahman, 2015).

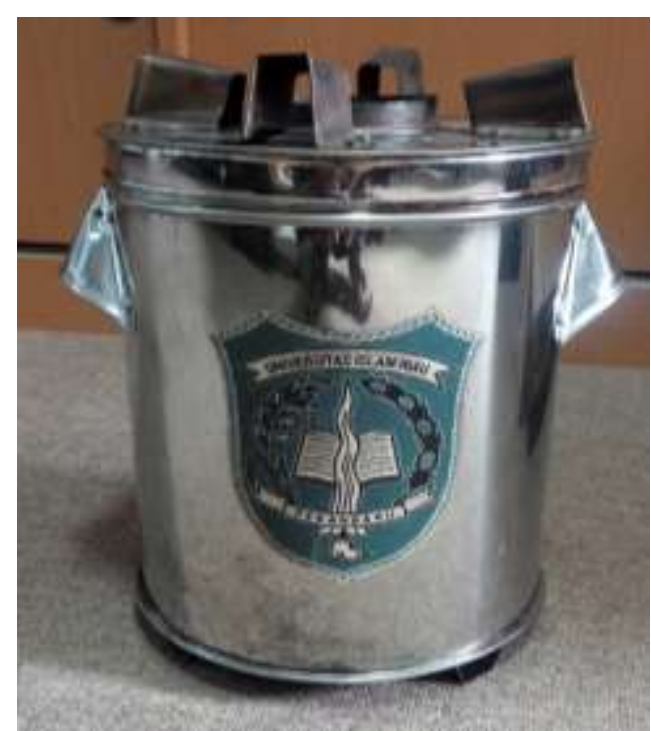

Gambar 2. Tungku biomassa semi gasifikasi pengembangan Prodi Teknik Mesin UIR

\section{METODE PELAKSANAAN}

Pengabdian kepada masyarakat ini dilakukan di desa Danau Pulai Indah kecamatan Kempas Jaya kabupaten Indragiri Hilir pada tanggal 8 Agustus 2016. Untuk mencapai tujuan yang telah direncanakan kegiatan ini diatur sedemikian rupa sehingga dapat berjalan dengan baik dari sebelum penyuluhan diadakan sampai akhir kegiatan dengan beberapa tahapan, yaitu,

1. Tahap persiapan

Tahapan ini dilakukan dengan menghubungi pihak kelurahan jauh hari sebelum kegiatan dilaksanakan. Hal ini dilakukan untuk menginformasikan pihak pimpinan desa akan maksut dan tujuan kegiatan serta manfaat yang didapatkan dari kegiatan ini. Hal ini juga ditujukan agar informasi mengenai pelaksanaan kegiatan pengabdian kepada masyarakat tersebar dengan baik sehingga pengetahuan tentang teknologi tepat guna ini tersampaikan kepada sebagian besar masyarakat. Selain itu, persiapan kelengkapan perangkat pada prototip kompor biomassa yang dipresentasikan sebagai model dicek dengan teliti agar permasalahan teknis tidak terjadi.

2. Tahap penyuluhan

Tahapan ini merupakan tahapan inti yang berhubungan langsung dengan masyarakat setempat. Pada tahapan ini kegiatan penyuluhan/sosialisasi kompor biomassa dilaksanakan dengan urutan pengenalan tentang pemanfaatan sumber daya alam. Kemudian dilanjutkan dengan penyampaian dampak-dampak buruk yang ditimbulkan dari penggunaan tungku tradisional berdasarkan data-data yang meyakinkan dari sumber-sumber terpecaya, memperkenalkan sebuah model kompor biomassa yang memiliki performa yang lebih baik, aman, serta serta hemat pemakaian bahan bakar, dan lain lain.

3. Tahap diskusi

Pada tahapan ini interaksi antara narasumber dan perserta dilaksanakan melalui tanya jawab langsung. Dan untuk membuat suasana lebih hidup, diskusi tidak hanya melibatkan dosen dan masyarakat, tetapi juga mahasiswa dari daerah local. Pada tahapan ini diskusi tidak hanya membahas tentang teknologi tepat guna kompor biomassa semi gasifikasi, tetapi juga menerima masukan dari masyarakat setempat tentang masalah-masalah lain yang mereka alami dan teknologi tepat guna lainnya yang mereka butuhkan. 


\section{HASIL DAN PEMBAHASAN}

\section{Pembahasan Kegiatan}

Gambar 3 sampai Gambar 5 menunjukkan suasana kegiatan ketika narasumber memberikan penjelasan kepada peserta penyuluhan, dilanjutkan interaksi tanya jawab dengan perserta penyuluhan dan penjelasan yang lebih spesifik tentang bagian-bagian kompor biomassa gasifikasi.

Penyampaian materi penyuluhanMateri penyuluhan tentang kompor biomassa yang disampaikan pada kegiatan ini meliputi penjelasan tentang kompor biomassa, aspek-aspek penting terkait kompor biomassa, alasan dan keuntungan yang diperoleh dengan menggunakan kompor biomassa, peranan kompor biomassa dalam mengurangi efek buruk hasil pembakaran, sejauh mana energi yang dapat dihemat dengan menggunakan kompor biomassa, serta menjelaskan model dan bagian-bagian dari kompor biomassa yang telah dirancang oleh Prodi Teknik Mesin Fakultas Teknik Universitas Islam Riau. Ceramah interaktif yang dilakukan dengan bantuan ilustrasi gambar dan foto pada slide power point sangat membantu peserta kegiatan dalam memahami informasi yang disampaikan. Metode ini juga memudahkan dalam penjelaskan contoh-contoh pemanfaatan sumber daya alam disekitar masyarakat yang tidak/belum termanfaatkan untuk diolah dan dijadikan bahan bakar yang dapat digunakan pada kompor biomassa. Pokok pembahasan yang disampaikan adalah sebagai berikut,

1. Teknologi tepat guna di rumah tangga,

2. Alasan memasak dengan menggunakan kayu/biomassa,

3. Kerugian memasak dengan menggunakan kompor biomassa tradisional,

4. Bahaya yang ditimbulkan oleh asap sisa pembakaran kompor tradisional,

5. Keuntungan memasak dengan rancangan kompor biomassa,

6. Model dan bagian-bagian dari rancangan kompor biomassa,

7. Bahan bakar yang dapat digunakan pada kompor biomassa.

Pengalaman-pengalaman yang telah dialami oleh peserta dalam hal memasak dengan menggunakan kompor/tungku tradisional maupun pertanyaan yang berhubungan dengan materi penyuluhan disampaikan pada sesi diskusi dan tanya jawab, sehingga materi yang disampaikan lebih jelas dipahami dan manfaat yang dirasakan terkait dengan masalah-masalah yang sedang dihadapi oleh kebanyakan orang tua. Selain itu hal-hal lain yang dirasakan oleh masyarakat terkait dengan cara pengolahan sampah untuk menjadi sesuatu yang bisa dimanfaatkan sebagai bahan bakar juga didiskusikan bersama untuk mencari solusi yang tepat dan sesuai dengan kondisi masyarakat setempat. Termasuk juga didalamnya membahas tentang teknologi-teknologi tepat guna yang dibutuhkan oleh masyarakat setempat.
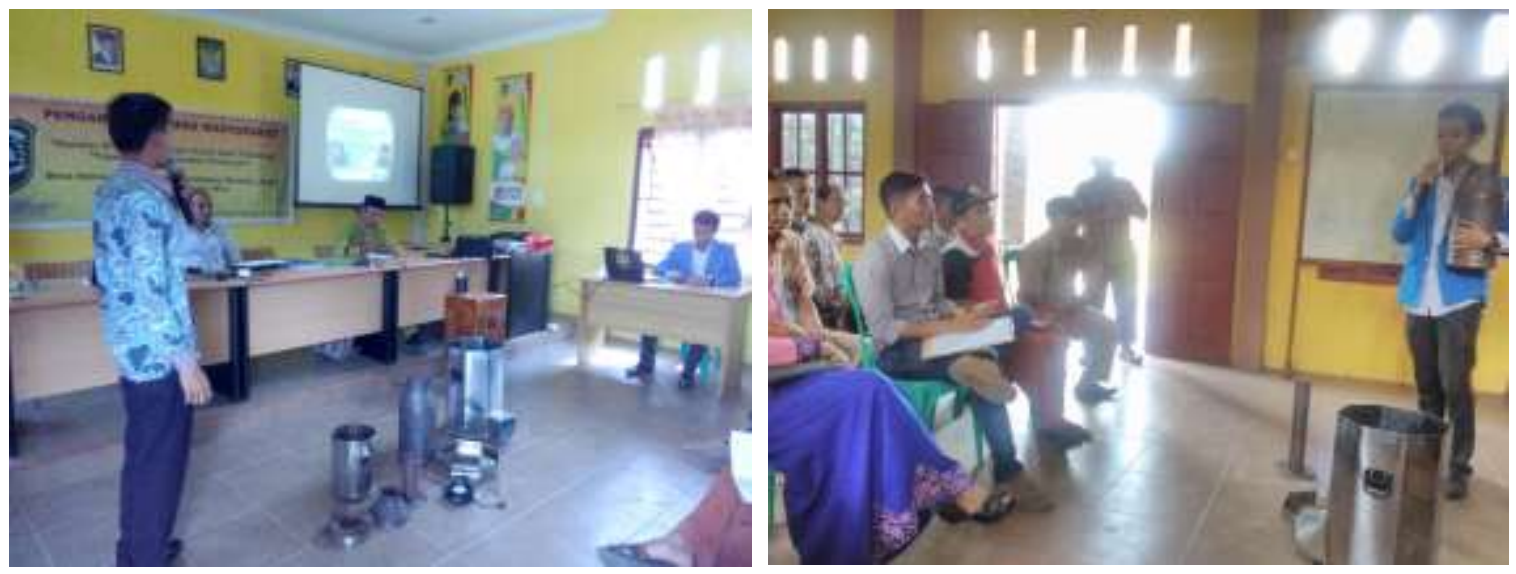

Gambar 3. Penyampaian materi penyuluhan oleh narasumber 
Buletin Pembangunan Berkelanjutan

Vol. 5 No. 3, Desember 2021 hal. 1-6

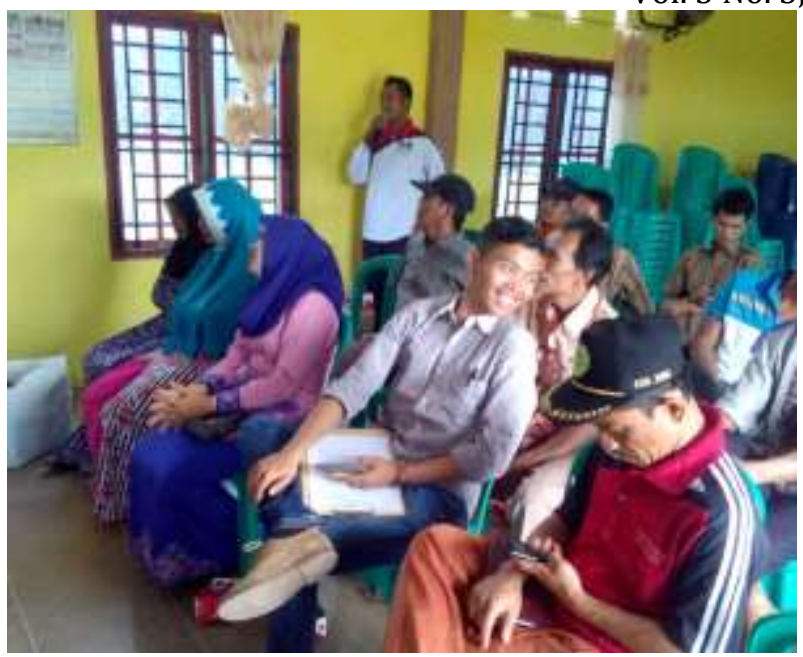

Gambar 4. Tanya jawab dengan peserta penyuluhan
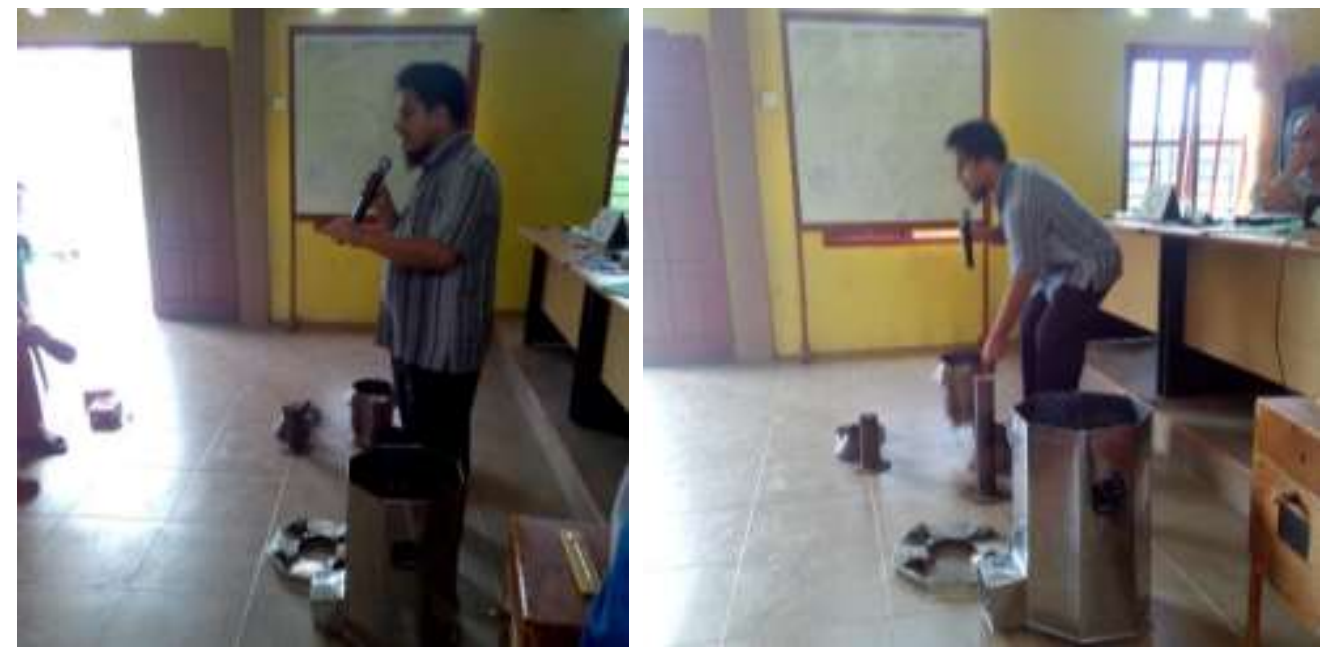

Gambar 5. Penjelasan detail tentang fungsi setiap bagian kompor biomassa

\section{Evaluasi Kegiatan}

Evaluasi pelaksanaan kegiatan dilakukan untuk mengidentifikasi faktor-faktor pendukung dan penghambat yang terjadi dalam melaksanakan program pengabdian pada masyarakat ini. Secara garis besar faktor pendukung dan penghambat tersebut dapat kami jelaskan sebagai berikut:

\section{a. Faktor Pendukung}

1) Tersedia fasilitas yang memadai berupa laptop, proyektor, kamera digital, pengeras suara dan pointer dalam kegiatan pengabdian pada masyarakat ini,

2) Antusiasme para peserta yang cukup tinggi terhadap materi penyuluhan,

3) Dukungan dari pihak Kantor Desa yang menyambut baik pelaksanaan kegiatan penyuluhan dan membantu tim pengabdian mengatur waktu dan tempat pelaksanaan kegiatan,

4) Ketersediaan dana pendukung dari Lembaga Pengabdian pada masyarakat (LPM-UIR) guna penyelenggaraan kegiatan pengabdian pada masyarakat ini

b. Faktor Penghambat

1. Peserta penyuluhan terdiri dari berbagai perbedaan kalangan usia dan latar belakang pendidikan sehingga ada kekhawatiran materi yang disampaikan tidak dapat ditangkap sepenuhnya, terutama untuk warga yang latar belakang pendidikannya sangat rendah.

2. Keterbatasan waktu untuk pelaksanaan penyuluhan sehingga beberapa materi tidak dapat disampaikan secara baik. 
3. Tempat pelaksanaan didalam ruangan sehingga tidak dapat dilakukan demostrasi untuk melihat bagaimana kinerja kompor biomassa dibandingkan kompor tradisional yang telah ada dimasyarakat.

\section{KESIMPULAN}

Program pengabdian pada masyarakat berupa penyuluhan mengenai keunggulan kompor biomassa dibandingkan kompor-kompor tradisional terhadap kesehatan dan penghematan bahan bakar ini diharapkan mampu menambah wawasan, pengetahuan dan mampu memberikan solusi terhadap permasalahan penggunaan kompor biomassa dalam kehidupan sehari-hari. Selain itu pada kesempatan ini juga diperkenalkan pengembangan kompor biomassa semi gasifikasi dan bagianbagian-bagian penting di dalam kompor biomassa semi gasifikasi hasil rancangan Program Studi Teknik Mesin Universitas Islam Riau. Dengan diperkenalkan bagian-bagian dari kompor biomassa semi gasifikasi diharapkan masyarakat sekitar dapat mencontohnya, membuat dan menggunakan model kompor tersebut untuk kebutuhan memasak. Selain itu bagi masyarakat yang memiliki kemampuan/skill dalam membuat kompor tersebut, maka hal ini dapat dijadikan sebagai sarana baru dalam meningkatkan taraf hidup mereka.

Program kegiatan penyuluhan ini disertakan dengan modul materi sehingga peserta dapat mengambil pelajaran/informasi mengenai perbandingan menggunakan kompor biomassa semi gasifikasi dengan komporkompor biomassa tradisional yang dipergunakan oleh masyarakat selama ini. Kegiatan ini mendapat sambutan sangat baik dari seluruh peserta dan dinas terkait yang terbukti dengan keaktifan peserta mengikuti penyuluhan dengan tidak meninggalkan tempat sebelum waktu penyuluhan berakhir, serta adanya permintaan masyarakat setempat untuk diadakan kembali kegiatan lanjutan tentang workshop cara pembuatan kompor biomassa semi gasifikasi.

\section{UCAPAN TERIMA KASIH}

Terimakasih kepada Universitas Islam Riau atas izin dan dukungan finansial sehingga kegiatan ini dapat berjalan dengan baik. Begitu juga halnya kepada pihak kelurahan desa Pulai Indah Kec. Kempas Jaya Kab. Indragiri Hilir, telah bersedia menerima kami dan menyebar luaskan informasi kegiatan ini kepada masyarakat desa Pulai Indah.

\section{DAFTAR PUSTAKA}

Adler, T., (2010). Better Burning, Better Breathing; Improving Health with Cleaner Cook Stoves. Enviromental Health Perspectives, 118(3). https://doi.org/10.1289/ehp.118-a124

Elfiano, E., Natsir, M., \& Indra, D. (2014). Analisa Proksimat Briket Bioarang Campuran Limbah Ampas Tebu dan Arang Kayu. In Seminar Nasional Teknik Mesin Universitas Trisakti.

Elfiano, E. Analisa Karakteristik Pembakaran Briket Tongkol Jagung dengan Proses Karbonisasi dan Non-Karbonisasi.

Giyanto, G. (2020). Kajian Preferensi Penggunaan Kompor Biomassa Pelet kayu Sebagai Alternatif pengganti Tungku Tradisional. In Prosiding Seminar Nasional NCIET. 1(1), 6-19.

Julita, R., Rionaldo, H., Andrio, D., \& Zulfansyah, Z. (2019). Performa kompor gasifikasi champion stove.

Pathak, U., Kumar, R., Suri, T. M., Suri, J. C., Gupta, N. C., \& Pathak, S. (2019). Impact of biomass fuel exposure from traditional stoves on lung functions in adult women of a rural Indian village. Lung India: Official Organ of Indian Chest Society, 36(5), 376.

Rahman, J. (2015). Perancangan Kompor Biomassa Yang Bebas Polusi. Jurnal Relevansi, Akurasi Dan Tepat Waktu (RAT), 4(1), 555-561.

Robin, L. F., Lees, P. S., Winget, M., Steinhoff, M., Moulton, L. H., Santosham, M., \& Correa, A. (1996). Wood-burning stoves and lower respiratory illnesses in Navajo children. The Pediatric infectious disease journal, 15(10), 859-865.

World Health Organization. (2014). World Health Statistics 